\title{
Formulation of Vermiwash and Humic Acid and its Application on Allium cepa
}

\author{
P. Prakash*, Umesh Prasad, Swetha Sunkar, N.M.D. Sai Krishna, \\ Akshay Atul Gala and Amit Kumar
}

Department of Biotechnology, Sathyabma University, Chennai, India.

http://dx.doi.org/10.13005/bbra/2064

(Received: 06 January 2016; accepted: 18 February 2016)

\begin{abstract}
The continuous use of chemical fertilizers is leading to the contamination of soil and adversely affects the flora and fauna. Look out for natural forms of fertilizers is unceasing. The aim of the present investigation was to determine the influence of vermiwash and humic acid and their combinations various concentrations on the growth of Allium cepa. Vermiwash and humic acid and combinations of vermiwash and humic acid are used as plant growth promoters in varying concentrations. In this study, the concentration of $3: 1.5 \%$ (vermiwash: humic acid) was found to be the most effective formulation which was manifested in increase in growth, soft shoots, number of branches, total carbohydrate content and total protein content followed by a concentration of $3: 2 \%$ (vermiwash: humic acid). This study was effective in formulating an efficient chemical free fertilizer that can be further used in agriculture on a large scale.
\end{abstract}

Key words: Humic acid, Vermiwash, Allium cepa; plant growth parameters

Agriculture is an art, science and industry of managing the growth of plants and animals for human use. Two major types of agricultural systems are followed in India i.e., modern agriculture and traditional agriculture. Modern agriculture makes use of chemical fertilizers, pesticides and herbicides but traditional agriculture makes use of cow dung and composting materials as fertilizers for crops. Increased use of chemical fertilizers over a long period of time has led to contamination of soil that further led to the contamination of food materials. Due to this, emphasis is laid on organic farming to improve the quality of food and health of the mankind. Organic farming is a system of natural farming that employs techniques such as green manure, crop rotation, compost and biological pest control, natural fertilizers limiting the use of petrochemical fertilizers

\footnotetext{
* To whom all correspondence should be addressed. Mob.: +91 9840522688;

E-mail: kpprakashmtech@gmail.com
}

and pesticides there by fulfilling the food and nutritional quality without depleting the natural soil system.

This situation led to the use of liquid fertilizers like vermiwash derived from vermicompost. Vermicompost in the soil favourably affects soil $\mathrm{pH}$, microbial population and soil enzyme activities ${ }^{1}$.Vermicomposts are produced from organic wastes through interactions between earthworms and microorganisms, and can be utilized as plant growth media or soil amendments. Vermiwash obtained from vermicompost is found to comprise of nutrients that are easily taken up by plants and hence play an important role in the plant growth and development. They are found to possess enzymes and secretions of earthworms that would stimulate the growth of the crops ${ }^{2}$. In the recent past, studies on humic acid revealed their potential as a supplement for plant growth. This is found to increase the water holding capacity and soil fertility there by positively influencing the growth of plants. 
In view of the advantages possessed by vermiwash and humic acid, the present study tries to develop a formulation comprising these components and study their effect on the growth of the plant Allium cepa.

\section{MATERIALSANDMETHOD}

\section{Preparation of Vermiwash}

Vermicompost is collected from local market in Chennai, TamilNadu, India. $100 \mathrm{~g}$ of vermicompost is mixed with $200 \mathrm{ml}$ of water thoroughly. The mixture is filtered after one hour and the vermiwash is collected and used for further experiments.

\section{Preparation of Humic Acid from Lignite}

Humic acid was extracted by following the procedures of International Humic Substances Society (IHSS). Crude Humic acid was used for all trials. Ten grams of coal (leonardite) was weighed and ground. It was then passed through a mesh sieve to get the fine particles and the sample was treated with $100 \mathrm{ml}$ of $4 \%$ Potassium Hydroxide and mixed thoroughly. Water soluble salt of humic acid thus formed was filtered through a Whatman No. 42 filter paper to separate it from insoluble residues and $1 \mathrm{ml}$ of concentrated hydrochloric acid was added to bring the $\mathrm{pH}<2$. The humic acid will get precipitated at the bottom of the beaker and the precipitate thus obtained is used for further experiments.

\section{Formulations used for the experiment}

The three categories of formulation includes

Vermiwash (1 to $10 \%)$; Humic acid ( $0.5 \%$

to 5\%); Vermiwash and Humic acid (1:0.5,2:1,3:1.5,4:2,5:2.5,6:3,7:3.5,8:4,9:4.5,10:5); and control trials were separately maintained.

\section{Effect of humic acid and Vermiwash on growth of Allium cepa seeds}

The effect of the above mentioned formulations was studied on Allium cepa. The seeds (10) were grown in petri plates and the treatments were given as per the above mentioned concentrations. The effect of the vermiwash and humic acid on seed germination of Allium cepa was studied by soaking the seeds in water which served as the control in one experiment, and two other experiments where the seeds were drenched in vermiwash, humic acid and their combinations. During the growth period, the germination rate was determined followed by finding the shoot length and root length.

Effect of humic acid and Vermiwash on growth of Allium cepa in pots

Garden soil was collected from the premises of University and mixed with $10 \%$ of cow dung and filled in $25 \times 10 \mathrm{~cm}$ size black color polythene bags. $1.5 \mathrm{~kg}$ of soil added in 40 bags and in each bag three onions were sown. After germination, the effect of humic acid and vermiwash was studied individually at different concentration followed formulated vermiwash with humic acid (1:0.5 to10:5\%). Bags were watered regularly and every 15 days monitoring plant height, no of branches and biochemical analysis such as total carbohydrates, total proteins contents were observed.

\section{RESULTSAND DISCUSSION}

The extraordinary ability of earthworms in the formation of soil and maintaining its fertility that plays a crucial role in balancing the ecosystem is well acknowledged in the past. Vermicompost is the compost which is a finely divided material with excellent porosity, water holding capacity, aeration, drainage and structure. It is prepared using earthworms and the nutrient quality of the vermicompost depends on the input material. Evidences exist stating that vermicompost remains a good promoter for the growth of plants by improving the biological, chemical and physical properties of the soil.

Vermiwash is the liquid usually obtained after the passage of water though the vermicompost. This is used as fertilizer as this is a mixture of secretory and excretory products of the earthworm and also includes the micronutrients of the soil. Therefore it is used for the growth of the plants and also acts as mild biocide ${ }^{1-15}$.

\section{Effect of vermiwash on Allium cepa seed germination}

Various concentrations of vermiwash were used to evaluate its effect on the growth of Allium cepa using germination rate, root length and shoot length as parameters. $\quad 100 \%$ germination was observed in the plates with $4 \%, 6$ $\%$ and $7 \%$ vermiwash. But at $4 \%$ concentration, the root and the shoot length were found to be highest with the average to be $7.4 \mathrm{~cm}$ and $5.8 \mathrm{~cm}$ 
respectively. The concentrations beyond $4 \%$ did induce the germination, root and shoot growth but $4 \%$ was identified to be ideal concentration for maximum growth.

Similar kind an effect was observed where in $10 \%$ Vermiwash was able to bring about $100 \%$ germination in the seeds of Hibiscus sabdariffa and Phaseolus vulgaris when used along with plant growth promoter gibberellic acid ${ }^{3}$.This reports suggested the use of $10 \%$ Vermiwash for effective

Table 1. Effect of various concentrations of vermiwash on the growth of Allium cepa seeds

\begin{tabular}{lccc}
\hline $\begin{array}{l}\text { Conc of } \\
\text { vermiwash (\%) }\end{array}$ & $\begin{array}{c}\text { Germination } \\
\text { rate (\%) }\end{array}$ & $\begin{array}{c}\text { Root length } \\
(\mathrm{cm})\end{array}$ & $\begin{array}{c}\text { Shoot length } \\
(\mathrm{cm})\end{array}$ \\
\hline 1 & 30 & $6.1 \pm 0.21$ & $3.44 \pm 0.14$ \\
2 & 40 & $6.5 \pm 0.08$ & $3.45 \pm 0.18$ \\
3 & 50 & $5.6 \pm 0.12$ & $5.33 \pm 0.15$ \\
4 & 100 & $7.4 \pm 0.08$ & $5.90 \pm 0.10$ \\
5 & 90 & $6.7 \pm 0.02$ & $4.37 \pm 0.15$ \\
6 & 80 & $6.9 \pm 0.05$ & $4.47 \pm 0.15$ \\
7 & 80 & $5.6 \pm 0.36$ & $5.13 \pm 0.12$ \\
8 & 60 & $5.4 \pm 0.09$ & $5.41 \pm 0.09$ \\
9 & 60 & $6.3 \pm 0.10$ & $5.44 \pm 0.14$ \\
10 & 70 & $5.3 \pm 0.16$ & $5.25 \pm 0.14$ \\
\hline
\end{tabular}

Table 2. Effect of vermiwash on the growth of Allium cepa in pots

\begin{tabular}{ccccc}
\hline $\begin{array}{c}\% \\
\text { Vermiwash }\end{array}$ & $\begin{array}{c}\text { Avg no. of } \\
\text { branches }\end{array}$ & $\begin{array}{c}\text { Avg shoot } \\
\text { length }(\mathrm{cm})\end{array}$ & $\begin{array}{c}\text { Protein } \\
(\mu \mathrm{g} / \mathrm{g})\end{array}$ & $\begin{array}{c}\text { Carbohydrate } \\
(\mu \mathrm{g} / \mathrm{g})\end{array}$ \\
\hline $1 \%$ & 4.00 & 6.00 & 110 & 80 \\
$2 \%$ & 7.66 & 11.66 & 165 & 60 \\
$3 \%$ & 8.66 & 18.66 & 125 & 160 \\
$4 \%$ & 11.00 & 20.33 & 220 & 260 \\
$5 \%$ & 6.33 & 19.66 & 90 & 210 \\
$6 \%$ & 6.33 & 19.00 & 165 & 150 \\
$7 \%$ & 8.00 & 18.7 & 160 & 140 \\
$8 \%$ & 6.66 & 18.00 & 155 & 110 \\
$9 \%$ & 4.00 & 6.00 & 160 & 100 \\
$10 \%$ & 6.66 & 14.33 & 150 & 80 \\
\hline
\end{tabular}

Table 3. Effect of various concentrations of humic acid on the growth of Allium cepa seeds

\begin{tabular}{lccc}
\hline $\begin{array}{l}\text { Conc of } \\
\text { vermiwash (\%) }\end{array}$ & $\begin{array}{c}\text { Germination } \\
\text { rate (\%) }\end{array}$ & $\begin{array}{c}\text { Root length } \\
(\mathrm{cm})\end{array}$ & $\begin{array}{c}\text { Shoot length } \\
(\mathrm{cm})\end{array}$ \\
\hline 0.5 & 20 & $0.25 \pm 0$ & $0.65 \pm 0.07$ \\
1 & 20 & $3.3 \pm 0.14$ & $3.3 \pm 0.14$ \\
1.5 & 100 & $3.8 \pm 0.14$ & $5.85 \pm 0.07$ \\
2 & 80 & $3.9 \pm 0.14$ & $5.5 \pm 0.14$ \\
2.5 & 80 & $3.35 \pm 0.35$ & $3.35 \pm 0.07$ \\
3 & 80 & $1.45 \pm 0.48$ & $3.35 \pm 0.35$ \\
3.5 & 100 & $3.2 \pm 0.14$ & $3.75 \pm 0.21$ \\
4 & 60 & $2.75 \pm 0.07$ & $2.9 \pm 0.00$ \\
4.5 & 40 & $4.5 \pm 0.14$ & $3.25 \pm 0.21$ \\
5 & 20 & $2 \pm 0.14$ & $1.15 \pm 0.07$ \\
\hline
\end{tabular}


seed germination but in the current study only $4 \%$ of Vermiwash was found to be sufficient for attaining $100 \%$ germination rate thereby stating its effectiveness in the growth of Allium cepa.

\section{Effect of vermiwash on Allium cepa Pot culture}

The effect of vermiwash on the growth of Allium cepa was also studied at the pot level where in the number of branches and shoot lengths were taken into consideration. Likewise, at this stage, the total protein and carbohydrate content was also determined to evaluate the effect of vermiwash on certain biochemical parameters and the results are provided in Table 2. From the results, it is observed that $4 \%$ vermiwash was ideal for the growth of seeds in the pot study. At this concentration, there is more number of branches with maximum shoot length. Moreover in this condition, there is high protein and carbohydrate content in the leaves of the plant.

Likewise, the positive effect of Vermiwash on the seeds of Vigna munga, Vigna radiate and Sesamum indicum was found where in there was an increase in the growth parameters like the root length, shoot length, number of twigs and leaves and total biomass ${ }^{4}$. A study conducted by Prabhu (2006) reported the use of vermiwash for the growth of seeds of cowpea and paddy crops ${ }^{5}$. The results showed an improved germination percentage and seedling vigour. This increased growth may be due to the proteases in the Vermiwash that may help in the germination and the amylases could be a simple carbon source that promotes plant growth and productivity ${ }^{6}$.

Table 4. Effect of humic acid on the growth of Allium cepa in pots

\begin{tabular}{ccccc}
\hline $\begin{array}{c}\% \\
\text { Humic acid }\end{array}$ & $\begin{array}{c}\text { Avg no. of } \\
\text { branches }\end{array}$ & $\begin{array}{c}\text { Avg shoot } \\
\text { length }(\mathrm{cm})\end{array}$ & $\begin{array}{c}\text { Protein } \\
(\mu \mathrm{g} / \mathrm{g})\end{array}$ & $\begin{array}{c}\text { Carbohydrate } \\
(\mu \mathrm{g} / \mathrm{g})\end{array}$ \\
\hline 0.5 & 6.66 & 9.00 & 150 & 110 \\
1.0 & 9.66 & 13.33 & 150 & 120 \\
1.5 & 9.33 & 23.33 & 160 & 160 \\
2.0 & 15.00 & 29.66 & 160 & 135 \\
2.5 & 9.33 & 24.00 & 170 & 130 \\
3.0 & 7.33 & 20.00 & 150 & 105 \\
3.5 & 7.33 & 11.66 & 145 & 100 \\
4.0 & 7.33 & 8.33 & 140 & 90 \\
4.5 & 10.5 & 14.00 & 135 & 70 \\
5.0 & 12 & 20.5 & 150 & 95 \\
\hline
\end{tabular}

Table 5. Effect of different combinations of humic acid and vermiwash on the growth of Allium cepa seeds and results of pot study

\begin{tabular}{|c|c|c|c|c|c|c|c|}
\hline $\begin{array}{l}\text { Conc of humic } \\
\text { acid and } \\
\text { vermiwash } \\
\text { (\%) }\end{array}$ & $\begin{array}{l}\text { Germination } \\
\text { rate (\%) }\end{array}$ & $\begin{array}{l}\text { Root } \\
\text { length } \\
(\mathrm{cm})\end{array}$ & $\begin{array}{l}\text { Shoot } \\
\text { length } \\
(\mathrm{cm})\end{array}$ & $\begin{array}{l}\text { Avg } \\
\text { length of } \\
\text { branches } \\
(\mathrm{cm})\end{array}$ & $\begin{array}{c}\text { Avg } \\
\text { length } \\
\text { of shoot }(\mathrm{cm})\end{array}$ & $\begin{array}{l}\text { Protein } \\
(\mu \mathrm{g} / \mathrm{g})\end{array}$ & $\begin{array}{c}\text { Carbohydrate } \\
\text { ( } \mu \mathrm{g} / \mathrm{g})\end{array}$ \\
\hline $1.5: 3$ & 100 & $6.17 \pm 0.15$ & $5.32 \pm 0.08$ & 8 & 11.33 & 125 & 250 \\
\hline $2: 04$ & 60 & $3.59 \pm 0.12$ & $1.87 \pm 0.05$ & 8 & 8.33 & 165 & 175 \\
\hline $2.5: 5$ & 60 & $3.40 \pm 0.28$ & $3.40 \pm 0.14$ & 3.33 & 2.66 & 90 & 110 \\
\hline $3: 06$ & 50 & $3.00 \pm 0.14$ & $2.55 \pm 0.07$ & 5 & 5.66 & 220 & 100 \\
\hline $5: 10$ & 20 & $1.55 \pm 0.21$ & $1.15 \pm 0.07$ & 6.33 & 8 & 140 & 50 \\
\hline
\end{tabular}




\section{Effect of Humic acid on Allium cepa seed germination}

The effect of humic acid on the growth of seeds was evaluated and the results are provided in Table 3. The results clearly indicate that humic acid (1.5\%) was ideal for the growth of Allium cepa seeds. At this concentration, there was 100 $\%$ germination with maximum growth of root (3.8 $\mathrm{cm})$ and shoot $(5.8 \mathrm{~cm})$.

These results go in accordance with various other reports that assert the beneficial property of humic acid as growth enhancer in plants. A study conducted by Patil et al. (2010) reported that the seeds of Triticum aestivum (L.) $c v^{7}$. Showed good response in terms of seed germination and vegetative growth when treated with humic acid. Enhanced performance of humic acid was noticed by Xue et al. (1994) in various crops like wheat, maize, cotton and rape seed when compared to diammonium phosphate and other chemical fertilizers ${ }^{8}$. It was also found to increase the length of the seedlins of lettuce and tomato and found to increase the nutrient content of okra ${ }^{9,10}$. In this line, Prakash et al. (2014) also reported that the germination rate of Raphanus sativus increased in the presence of humic acid ${ }^{11}$.

Effect of Humic Acid on Allium cepa in Pot Study

Various reports suggested the use of humic acid in particular concentrations as a factor that promotes growth of the roots and aerial pots of several plants and also encouraged the absorption of nutrients. The effect of humic acid on the growth of Allium cepa in pot study was conducted along with the estimation of protein and carbohydrate content. In this study, it is observed that $2 \%$ humic acid is able to bring about maximum growth of the plant where the average number of branches is 15 with significant amount of protein $(160 \mu \mathrm{g} / \mathrm{g})$ and carbohydrate $(135 \mu \mathrm{g} / \mathrm{g})$.

This increase in growth parameters could be because of the uptake of minerals that would promote the root length and further enhance the weight of the crops ${ }^{12-18}$. Humic acid plays an important role in freeing up the nutrients in the soil and making them available for the plants. They are also known to chelate micronutrients and thereby increase their bioavailability ${ }^{19}$.
Development of formulation with vermiwash and humic acid and its effect on the seed germination and plant growth

Though not exactly termed as organic fertilizers, humic acid and vermiwash indirectly play a crucial role in promoting the growth of the plants and hence they act as growth supplements. The combined effect of vermiwash and humic acid in various concentrations on the growth of Allium sepa seeds followed by growth in pots was estimated and the results are provided in Table 5.

Different concentrations of humic acid and vermiwash were used to evaluate their combinatorial effect on the growth of Allium cepa. It was found that humic acid and vermiwash in the ratio $1.5 \%$ and $3 \%$. At this concentration, the germination rate was $100 \%$ with maximum root and shoot lengths. Lower concentrations of humic acid and vermiwash were found to be favourable for the growth of the seeds as higher concentrations tend to reduce the germination as

well as the growth parameters. Similarly the combined effect of humic acid and vermiwash was studied when the seeds were grown in pots. Important parameters like number of branches and shoot length were studied along with protein and carbohydrate content. It was found that in pot study also the ideal concentration of humic acid and vermiwash for the growth of plants was $1.5: 3$ $\%$ respectively. Hence the ideal concentration of humic acid and vermiwash for the maximum growth of Allium cepa was found to be 1.5 : $3 \%$.

Zea mays were cultivated in fields using vermiwash as biofertilizer which majorly reflected on the production of leaves with application time ${ }^{3}$. Zea mays was cultivated in fields using vermiwash as biofertilizer which majorly reflected on the production of leaves with application time ${ }^{20}$. Further attempts were successful in using vermiwash obtained from kitchen, agro and animal wastes for the growth of plants ${ }^{21}$. Earlier studies have suggested the beneficial property of humic acid on the growth of certain plants like Spirulina plantensis, Pleurotus florida, Stevia rebaudiana and Morus alba also formulated of seaweed liquid fertilizer using with humic acid and effects of Arachis hypogaea was reported thereby strongly advocating the suitability of humic acid to different types of plants and promoting their growth ${ }^{24-26}$. 
Independently, the concentration of vermiwash and humic acid required for promoting the growth of seeds and plants was found to be $4 \%$ and $1.5 \%$ respectively. But when used together the required concentration for maximum growth was $3 \%$ and $1.5 \%$ respectively. Vermiwash is considered to be a nutritious material as it contains the various secretions of earthworms including enzymes that may further stimulate the growth of plants. Likewise humic acid is known to enhance soil fertility and water holding capacity. Hence using a combination of humic acid and vermiwash would definitely improve the overall standards of the soil which further facilitates the growth of the plants $^{2,22,27 .}$

\section{CONCLUSION}

The present study reported the favorable effect of humic acid and vermiwash on the growth of Allium cepa. Three sets of experiments were carried out where in the seeds on Allium cepa were grown separately using humic acid and vermiwash and vermiwash and humic acid in combination in various concentrations. The ideal concentration of humic acid and vermiwash was found to be 1.5 $\%$ and $4 \%$ independently, while $1.5: 3 \%$ was found to be the ideal concentration when used in combination. Therefore this study successfully demonstrates the use of these organic products as growth supplements for plants and suggests the possibility of using these as biofertilizers.

\section{REFERENCES}

1. Maheswarappa HP, Nanjappa HV, Hegde MR. Influence of organic manures on yield of arrowroot, soil physico-chemical and biological properties when grown as intercrop in coconut garden. Ann Agr Res. 1999; 20:318-323.

2. Kale R.D.Earthworms. Nature's gift for utilization of organic wastes. In earthworm $\mathrm{s}$ ecology.Edwards, C.A (Ed.) Crcpress LLC. BOCCA. Raton, Florida. 1998; 355-376.

3. Mujeera Fathima and Malathy Sekar Studies on Growth Promoting effects of Vermiwash on the Germination of Vegetable Crops Int. J. Curr. Microbiol. App.Sci. 2014; 3(6) 564-570

4. Hatti S.S., Londonkar R.L., Patil S.B., Gangawane A.K. and Patil C.S., Effect of Perionyxexcavatusvermiwashon the growth of plants, Journal of Crop Science., 2010; 1(1):
01- 05.

5. Prabhu M. J. Coconut leaf vermiwash stimulates crop yield. The Hindu Newspaper, 28th December, In: Science and Technology section. 2006.

6. Zambare VP, Padul MV, Yadav AA, Shete TB () Vermiwash: biochemical and microbiological approach asecofriendly soil conditioner. ARPN J Agric Biol Sci. 2008; 3(4):1-5.

7. Patil R.B. , Mokle S.S. and Wadje. Effect of potassium humate on seed germination, seedling growth and vegetative characters of Triticum aestivum (l.) Cv. Lokvan 1 International Journal Of Pharma And Bio Sciences 2010; 1(1): 1-5.

8. Xue SC, Liu DC, Tong DY, Han JM, Li YR.. Studies on the effects and mechanism of humic acid compound fertilizer. J. Hebei. Agric. Univ. China. 1994; 17: 24-27.

9. Piccola A, Celano and Pietramellara G, Journal of Biology and Fertility of Soils, 1993; 16(1): 1115.

10. Mustafa Paksoy, Ö Türkmen and A Dursun; African Journal of Botechnology, 2010; 9(33): 5343-5346.

11. Prakash P, Alien Maria Roniesha M, Sai Nandhini R, Masilamani Selvam M, Thirugnanasambandam R, Stanley Abraham L. Int J ChemTech Res 2014; 6(9): 4180-4185.

12. Maggioni A., Varanini Z., Nardi S., Pinton R. Action of soil humic matter on plant roots: Stimulation of ion uptake and effects on $\mathrm{Mgg}^{2+}$, $\mathrm{K}+$ ) ATPase activity. Science of the Total Environment, 1987: 62: 355-363.

13. De Kreij C., Basar H. Effect of humic substances in nutrient film technique on nutrient uptake. Journal of Plant Nutrition.1995; 18: 793-802.

14. Mackowiak C.L., Grossl P.R., Bugbee B.G. Beneficial effects of humic acid on micronutrient availability to wheat. Soil Science Society of America Journal, 2001; 56: 1744-1750.

15. Kauser A. Malik, Azam F. Effect of humic acid on corn seedling growth. Environmental and Experimental Botany,1985; 25: 245-252.

16. Cenellas L.P., Olivares F.L., Okorokova-Facanha A.L., Facanha A.R. Humic acids isolated from earthworm compost enhance root elongation, lateral root emergence and plasma membrane $\mathrm{H}$ ATPase activity in maize roots. Plant Physiology, 2002; 130: 1951-1957.

17. Chen Y., Clapp C.E., Magen H. Mechanisms of plant growth stimulation by humic substances: The role of organic-iron complexes. Soil Science and Plant Nutrition, 2004a; 50: 1089-1095.

18. Chen Y., Nobili M., Aviad T. Stimulatory effect of humic substances on plant growth. In: Magdoft F., Ray R. (eds): Soil Organic Matter 
in Sustainable Agriculture. CRC Press, Washington. 2004b.

19. Hussein Khaled and Hassan A. Fawy. Effect of Different Levels of Humic Acids on the Nutrient Content, Plant Growth and Soil Properties under Conditions of Salinity Soil \& Water Res., 2011; 1: 21-29

20. Manyuchi M, Kadzungura M, Phiri L, and Muredzi P. International Journal of Scientific Engineering and Technology 2013; 2(7):638641.

21. Gorakh Nath and Keshav Singh. J Central European Agr 2009;10(4):417-426

22. Salman SR, Abou-hussein SD, Abdel-Mawgoud and El-Nemr MA. J App Sci Res 2005;1(1): 5158

23. Prakash P, Dhanalakshmi PK, Anusha B. Recent Res Sci Technol 2011;3(1):87-89.
24. Prakash P, Samundeeswari R, Vivek C, Chitra Devi A. World J Sci Technol 2011;1: 28-31.

25. Prakash P, RajaKumari P, Aishwarya V, Thanuja Polani, Archana Priya, Venugopal and Thirumurugan A International Journal of Agricultural and Food Science 2012; 2(1): 3031.

26. Prakash P, Sudipta Medhi , Swaraj Saikia , Narendrakumar G, Thirugnanasambandam and Stanley Abraham L. Production, Formulation and Application of Seaweed Liquid Fertilizer using Humic Acid on Growth of Arachis hypogaea. Biosciences Biotechnology Research Asia, 2014; 11(3), 1515-1519.

27. Edwards, C.A., Bohlen P.J., D.R. Linden and S. Subler, Earthworms in agro ecosystems. In: Earthworm Ecology and Biogeography in North America. (Hendrix, P.F. Ed.), Lewis Publisher, Boca Raton, 1993; 185-213. 